\title{
Grundtvig og Rødding Højskole
}

\author{
Af Thorkild C. Lyby
}

I 1998 udsendte Helge Grell sin bog Vision og virkeliggфrelse, der, som undertitlen angiver, er anlagt som en sammenligning mellem Grundtvigs højskoletanker og de højskolesyn, man finder hos lederne af den højskolebevægelse, der faktisk udviklede sig. ${ }^{1}$ Et af de forhold, man måtte undre sig over ved dette i og for sig fortjenstfulde arbejde, var den stedmoderlige behandling, der blev Rødding Højskole og dens mænd til del. Grunden hertil er Grells specielle opfattelse af Røddings forhold til Grundtvig, som den f.eks. fremgår af den måde, hvorpå han forstår Grundtvigs tale på Skamlingsbanken i 1844 og den deri indeholdte hilsen til den på dette tidspunkt endnu ikke oprettede skole i Rødding. Grell skriver:

Grundtvig tænker her på den nyoprettede højskole i Rødding (H-G. s1, s. 1.32.) Han vil gerne medvirke til en sådan skoles virksomhed, hvis betydning ligger på det nationale område, men det er hans håb, at han skal nå at se en højskole realiseret, som bygger på, hvad der gav ham 'Øie for Menneske-Livets og Verdens L $\varnothing \mathrm{b}$ ' (sst.s.134). Med disse sidste ord synes Grundtvig allerede i 1844 at være opmærksom på, at skolen i Rødding ikke, i alt fald i sin start, bygger på hans egne højskoletanker. ${ }^{2}$

Med andre ord: Rødding var national, men ikke grundtvigsk! Og derfor var Grundtvig forbeholden i sin anerkendelse af den!

Nu rejser alene Grells henvisninger visse spørgsmål. At de gælder Borups og Schrøders Haandbog, bind I, er klart. ${ }^{3}$ Det er ligeledes klart, at den første er undsluppet korrekturlæsningen, så at man selv må oplede det refererede sted. Så vidt jeg kan se, må det være det anførte værks s. 137, der menes. Den anden henvisning er klar nok, men forkert. Det anførte citat står ikke s. 134, men s. 139-140.

Vigtigere er dog spørgsmålet, om Grells tolkning af de anførte steder er korrekt. Det mener jeg ikke. Det har ikke været mig muligt at finde antydning af et forbehold over for Rødding-initiativet i Grundtvigs tale - heller ikke i de citerede steder. På s. 137 udfolder han, hvor vigtigt for den danske tunge det er, at der rejses en dansk højskole. Henvendt til slesvigerne fortsætter han: 
Og har jeg forstaaet Eder ret, da er det ogsaa netop en saadan "Dansk Høiskole«, I, af Kæmpe-Aandens Drift, har allerede gjort det første Skridt, Kæmpe-Skridtet til at rejse, og for dermed at $\emptyset$ nske Eder og Danmark, Nordens Aand og Menneske-Slægten til Lykke, derfor var det egenlig, jeg tog her til Orde ...

I det umiddelbart følgende afsnit erklærer han, at en dansk højskole i mange år var hans sødeste drøm og mangelen deraf hans bitreste savn. Derfor (!) henstiller han i næste afsnit (s. 138) til slesvigerne, at de standhaftigt fuldender, hvad de så kækt har begyndt, nemlig at rejse en højskole i deres midte. På s. 138-139 fortsætter han, at de ikke skal lade sig standse af, at der ikke findes mønster for en sådan skole i kongeriget. Slesvigerne har både folkehistorisk og kirkehistorisk ret til ikke blot at hedde danske, men endog til at gå i spidsen som danske mærkesmænd. Det er kun naturligt, at de også gør det skolehistorisk. Grundtvig lægger ikke skjul på, hvor meget han har sørget over, at den danske højskole ikke blev grundlagt i Sorø, som han havde håbet; men i direkte fortsættelse heraf erklærer han, at han nu kan se, at Danmarks skole må bygges, hvor Danmarks rige og Danmarks kirke oprandt, nemlig i hertugdømmet, hvor dansken alene har mod til at ligne sig selv.

Det afsnit, hvortil den anden af Grells henvisninger sigter (s. 139140), indledes med ordene: »Derfor op, I Danske Markes-Mand, Haand paa Værket!« Under hensyn til det foregående kan mærkes-mændene kun forstås som slesvigerne. Og længere nede står der så:

Alt hvad jeg kan bidrage til, at Eders Danske Høiskole kan blive en »Mimers-Brønd«, hvortil Konger ride, for at søge Raad, det skal være uspart; thi for min Person har jeg intet Ønske meer i denne Verden, saa jeg $\emptyset$ nsker kun at leve lidt endnu, for ikke at tage med mig i Graven hvad der gav mig Øie for Menneske-Livet og Verdens $L \phi b$...

Dette kan kun forstås som et tilsagn om ubegrænset støtte til Rødding. Det må være helt umuligt $\mathrm{i}$ de citerede ord at se et forbehold fra Grundtvigs side over for Rødding. Ordene om, at han kun $\varnothing$ nsker at leve lidt endnu, må formodentlig netop betyde, at han ønsker at se højskolen i Rødding som levende virkelighed - hvad den jo på det tidspunkt endnu ikke var. Jeg kan derfor ikke se rettere, end at han her lyser den 
slesvigske højskoleplan i kuld og køn; og som bekendt kom hans tale da også for mange til at stå som skolens egentlige indvielsestale.

Når dette er sagt, skal det på den anden side indrømmes, at spørgsmålet om Røddings grundtvigske præg og dens forhold til Grundtvig ikke er uproblematisk. Det er ikke berettiget i så høj grad, som Grell gør det, at se bort fra Rødding i en behandling af den tidlige grundtvigske højskole. Men det skal indrømmes, at der netop i Røddings tidligste historie er forekommet alvorlige brydninger omkring spørgsmålet om skolens grundtvigske karakter. Og det skal ligeledes indrømmes, at der er en vis tvetydighed over Grundtvigs forhold til den. Der kan derfor være grund til at se nærmere på begge disse spørgsmål.

Først må man dog stille spørgsmålet, hvad det overhovedet vil sige, at en højskole er grundtvigsk. Ordet er jo ikke éntydigt. Ikke alene kan den grundtvigske inspiration i praksis udmøntes på mange forskellige måder - hvad det moderne danske højskolebillede tydeligt viser. Men også ud fra et mere teoretisk synspunkt kan der lægges forskellige indhold i ordet. Man kan vælge at forstå det i snævrere forstand, således at man analyserer Grundtvigs eget begreb om folkelighed og derefter undersøger, i hvilken grad hans disciple har fattet dette begreb og respekteret det i deres skolearbejde. I en sådan undersøgelse vil de fleste højskolefolk sandsynligvis få dumpekarakter, især hvis man i en sådan analyse vil sætte folkeligheds-begrebet i forbindelse med Grundtvigs $\emptyset$ vrige tankeverden. Hans tænkning var så original og rummede så vide perspektiver, at næppe nogen af hans elever var i stand til at løfte hele arven efter ham. For så vidt kunne man spørge, om nogen endnu har været i stand til det.

Men man kunne også anlægge et mere historisk syn og spørge, hvilke skoleinitiativer der rent faktisk har været inspireret af Grundtvig hvor fuldstændigt eller ufuldstændigt man ellers har forstået ham. Med en sådan tilgang vil nok betydeligt flere skoler kunne anerkendes som grundtvigske. Det vil desuden være et lettere og mere éntydigt kriterium at arbejde med, og det vil på denne måde blive ret let at skelne mellem grundtvigske og ikke-grundtvigske skoler.

Muligvis vil en sådan fortolkning af ordet virke utilfredsstillende på mere dogmatisk orienterede forskere, for hvem de såkaldte højskoleskrifter må være ene afgørende. Men man skal ikke glemme, at de næsten alle er skrevet, før der endnu eksisterede nogen højskole; og man skal heller ikke glemme Grundtvigs respekt for virkeligheden, der som 
bekendt er alle tings prøve - in casu den højskole-virkelighed, der udviklede sig og viste sig frugtbar.

Faktisk har han selv lagt op til denne skelnen. Han har udtrykkeligt fralagt sig ethvert $\varnothing$ nske om at ville programmere den praktiske udformning af højskolen og dens arbejdsformer på forhånd. I to utrykte udkast fra 1836 afviser han således tanken om at ville opstille nøjagtige planer eller timesedler for den muntre, levende og frugtbare vekselvirkning, der skal finde sted på højskolen. Livet kan ikke beskrives, før det er levet! ${ }^{4}$ I Skolen for Livet fra 1838 erklærer han, at han egentlig slet ikke kan indlade sig på at redegøre for indretningen af den danske højskole. Alt levende menneskeligt - og derfor også højskolen - må fødes først, før man ved, hvilken hue der vil passe til hovedet. Hvis man vil udvikle en folkelig skole, må den indrettes efter folkets hoved og ikke efter enkeltmandens - hvilket vil sige, at man så vidt muligt må lade indretningen skabe og udvikle sig selv. Livsudviklingen kan ikke følge andre regler end naturlovene, og livsoplysningen må rette sig efter livet, som det virkelig forefindes. Det ville derfor være vanskeligt nok historisk at beskrive det, der må være hovedsagen i højskolen, nemlig det levende, det fælles og almindelige, der må være dens sjæl og øjemed: folkenaturens hensigtsmæssige udvikling og oplysning på modersmålet til fædrelandets gavn og kongens glæde; men at udregne det matematisk eller foreskrive det skematisk lader sig på ingen måde gøre. ${ }^{5}$

At han virkelig mente dette, fremgår bl.a. af hans ubetingede anerkendelse af Christen Kolds virke - idet alle jo er enige om, at dette ikke stemte med Grundtvigs oprindelige højskoletanker. ${ }^{6}$ Man bør derfor ikke optræde alt for håndfast, hvis man ud fra et rent teoretisk udgangspunkt vil afgøre, hvilke skoler der var grundtvigske, og hvilke der ikke var det. Egentlig mener jeg ikke, man kan stille andre krav til en skole, der skal kaldes grundtvigsk, end at den skal være ledet af folk, der vedkender sig en inspiration fra Grundtvigs højskoletanker, at de bevidst prøver at omsætte denne inspiration i praksis, og at man i denne deres praksis kan genkende væsentlige grundtvigske tanker om folkelighed og folkeoplysning.

Ser vi nu på udviklingen, der førte til oprettelsen af Rødding Højskole, er det klart, at der er to interesser, der driver den fremad, nemlig dels en national dansk interesse og dels en grundtvigsk. For klarheds skyld skal i det følgende begge disse interesser samt deres indbyrdes forhold skitseres. 
Baggrunden for den første er den vågnende nationalbevidsthed både på tysk og på dansk side. Denne måtte resultere i et modsætningsforhold dels mellem den tyske embedsmandskultur og den danske folkekultur i Nordslesvig, dels mellem det dansktalende Nordslesvig og de sydligere, tysktalende egne. I 1834 fandt de første valg til stænderforsamlingerne sted, og i 1836 begyndte stænderforsamlingen i Slesvig at virke. Derved fik man en kraftig påmindelse om, i hvor h $\varnothing \mathrm{j}$ grad Nordslesvigs dansktalende landbefolkning savnede den dannelse, der kunne sætte den i stand til at hævde sig både kulturelt og politisk og således udnytte de muligheder, stænderforfatningen gav den. Det bet ød, som »En Nordslesviger « gjorde gældende i Haderslev-avisen Dannevirke i 1841, at de dansksindede, nordslesvigske bønder var nødt til enten at vælge folk af deres egen midte, der sandsynligvis var dårligt rustede til at varetage hvervet, eller at vælge tysk uddannede folk, der ville arbejde direkte imod deres interesser. Som middel til afhjælpning af denne misère foreslog »Nordslesvigeren« oprettelsen af »høiere Dannelsesanstalter for Bondestanden « i Nordslesvig. ${ }^{7}$

Da nationale, sociale og politiske interesser på den tid og i disse områder naturn ødvendigt måtte hænge sammen, måtte det imidlertid fra første færd stå klart, at danske skoler kunne komme til at spille en rolle i alle disse tre retninger. Det ville derfor være mærkeligt, om man i Nordslesvig ikke var opmærksom på de højskoletanker, som Grundtvig netop på denne tid var ved at udvikle, og som netop inddrog alle disse perspektiver.

Det var man da også. Den 7. november 1840 bragte Dannevirke, der var startet i 1838 som et nationalt kamporgan, en sympatisk anmeldelse af Grundtvigs Bøn og Begreb om en dansk Høiskole i Soer. Anmeldelsen var uden underskrift og må vel derfor tillægges redaktøren, P. C. Koch. Den nationale og den grundtvigske interesse har således fra første færd været sammenknyttet. I $\varnothing v$ rigt betegner Koch i et brev til Christian Flor fra 1837 sig selv som »en ægte Grundtvigianer «. ${ }^{8}$

I den følgende tid diskuteredes spørgsmålet om oprettelse af en dansk skole livligt i Dannevirke, og i begyndelsen af 1840'erne skete der en række begivenheder, der skulle komme til at berede jordbunden. Den 11. november 1842 talte Peter Hiort Lorenzen dansk i den slesvigske stænderforsamling - til voldsom forargelse på tysk side og tilsvarende begejstring på dansk. Den nationale kamp var hermed en kendsgerning. Den 21. februar 1843 hyldedes Hiort Lorenzen ved den legendariske fest i Sommersted, hvor den unge Laurids Skau fik sit gennembrud som 
folketaler, og hvor den egentlige organisering af den danske bevægelse i Sønderjylland begyndte. Den 12. juni 1843 dannedes Den Slesvigske Forening i Haderslev, og den 14. august kunne den fremlægge en færdig plan for en folkehøjskole, udarbejdet af Christian Flor.

Dermed er vi nået til den mand, som frem for nogen må kaldes Rødding Højskoles åndelige fader. Siden 1826 havde han været dansk lektor og titulær professor i Kiel. Her måtte han erkende, at kløften mellem tysk og dansk var større, end han havde ventet, og at man stod over for et massivt pres i retning af at fortyske hele Sønderjylland. ${ }^{9}$ Han udviklede sig nu hurtigt til at blive en af de mest betydelige forkæmpere for danskheden i Sønderjylland - den danske bevægelses kommanderende general, som Laurids Skau kaldte ham. ${ }^{10}$ Han var således en drivende kraft bag oprettelsen af Dannevirke, og han var en nær ven af P. C. Koch.

Det nationale perspektiv over Flors virke er således klart nok. Men hans forhold til Grundtvig er ikke mindre klart. Til Ludvig Schrøder har han sagt, at han, fra han læste Grundtvigs ældste skrifter, blev vundet for hans historiske livsanskuelse, og at han aldrig siden kom bort fra den. I september 1829, da Grundtvig passerede Kiel på vej hjem fra England, indbød Flor ham til middag for at lære ham og hans tanker nærmere at kende. ${ }^{11}$ Forholdet blev på afgørende måde befæstet ved Flors læsning af Nordens Mythologi og Haandbog $i$ Verdens-Historien, der syntes ham at åbne udsigt til »en hel ny Verdens-Anskuelse eller ... et nyt filosofisk System«, der kunne sammenlignes med Kants, Schellings eller Hegels. I et brev til P. C. Koch fra 1837 skrev Flor, at han arbejdede lige ivrigt for Grundtvigs teologiske og historiske anskuelse, for Rasks sproglære og for den nordiske treenighed. Hans erfaring tvang ham endog til at anse sig selv for at være den eneste, der havde forstået Nordens Mythologi, bortset fra Grundtvig selv. Han skrev en udførlig anmeldelse af den, som ikke så meget tog form af en kritik som af en indføring i dens tankegang og et forsøg på at gøre den lettere tilgængelig for andre. Netop derfor afslog to forskellige tidsskrifter at trykke anmeldelsen, mens Grundtvig selv godkendte den og sagde, at Flor havde truffet hans mening på en prik. ${ }^{12}$ I 1856 skrev Flor:

Jeg tilstaar, at jeg ganske deler Grundtvigs Anskuelse af Nordens Aand og af Nordens Myther, og at jeg aldrig har kunnet tilegne mig nogen anden. Hans Fremstilling og Forklaring af dem, hvilken man 
ofte har fundet uforstaaelig og urimelig, har altid forekommet mig at være den naturligste og forstaaeligste. ${ }^{13}$

Beundringen for Grundtvig og bekendelsen til hans tanker fastholdt Flor hele sit liv. I 1856, da de havde haft en konflikt om sammensætningen af Rødding Højskoles bestyrelse, beklagede han over for L. C. Hagen, at han skulle stå som modstander af Grundtvig,

hvis Dom jeg plejer at lytte til som ingen Andens, og som jeg saa ofte med Taknemmelighed har kaldt og, trods denne Sag og dens mulige Følger, skal vedblive at kalde min aandelige Mester og Herre. $^{14}$

I 1860, da han - fejlagtigt - troede, at Grundtvig var dødssyg, skrev han til Sofus Høgsbro:

- ham vil jeg komme til at savne, uagtet jeg kun sjelden talte med ham, eller følte Trang til at tale med ham. Men jeg vidste dog, hvor han var at finde, hvis Blik gik i samme Retning som mit, kun at hans Øje var langt skarpere og sikkrere end mit; derfor var jeg rolig, om jeg end på min Vej blev så langt bag ved ham, at jeg knap фjnede, hvor han var. ${ }^{15}$

Den grundtvigske klang er også umiskendelig i det brev, han i 1865 skrev til Hans Sveistrup, og hvori han skildrer motiverne for oprettelsen af Rødding Højskole. Han skriver her, at det ikke har været Slesvig som geografisk begreb, der har interesseret ham, men interessen for slesvigerne selv, »hvis aandelige og hjertelige Liv jeg vilde bidrage Mit til at frelse. «Han udvikler videre, hvorledes ingen fællesånd vil kunne finde bolig hos et folk, der har mistet sit modersmål, og at denne katastrofe netop var ved at ske i Slesvig. Derfor besluttede han sig til at blive »missionær «, ganske vist ikke blandt fremmede, men blandt sine landsmænd, og tilsyneladende mere i menneskelighedens end i kristendommens tjeneste. »Men Maalet var det samme: det er kun virkelige Mennesker som kan blive rette Kristne «. ${ }^{16}$

Flor bekendte fra første færd ganske åbent, at hans folkeoplysende arbejde var bestemt af den grundtvigske inspiration. Da der i 1841 var planer fremme om at oprette en realskole for den nordslesvigske ungdom, erklærede han: 
- hvad jeg anseer for Menigmands aandelige og politiske Frelse, faaer jeg neppe Nogen til at begribe, det er nemlig netop den samme »Høiskole-Idee «, som Grundtvig har flere Gange skrevet om og tilsidst ifjor udgivet en lille Piece om: 'Dansk Høiskole i Sorø', men som naturligviis intet Menneske har forstaaet et Ord af ... I Sammenligning med en saadan 'Folke-Høiskole' har en Realskole for mig næsten ingen Interesse ${ }^{17}$

Som Grundtvig anså Flor bønderne for at være folkets egentlige grundstamme og derfor den stand, der skulle mobiliseres, hvis danskheden i Sønderjylland skulle reddes. Han kunne endog tale om, hvordan han skulle føre sin nordslesvigske bondehær frem. ${ }^{18}$ Med fuld ret erklærer A. Pontoppidan Thyssen: »Nordslesvig blev gennem Flor det første værksted for det grundtvigsk-folkelige eksperiment « ${ }^{19}$

I januar 1843 knyttedes gennem Hiort Lorenzen kontakt mellem de danske s $\varnothing$ nderjyder og de k $\varnothing$ benhavnske nationalliberale. I maj dannedes i København »Den Slesvigske Hjælpeforening «, der bl.a. nedsatte en komité til danske undervisningsanstalters fremme i Slesvig, kaldet Syvstjernen, hvis ledende medlem var Grundtvigs gamle modstander H. N. Clausen. Utvivlsomt var det Syvstjernens plan at oprette en dansk latinskole og et dansk seminarium i Nordslesvig. Men sønderjyderne selv så anderledes på sagen. Således arbejdede den grundtvigske præst i Mjolden, L. C. Hagen ivrigt for at overbevise dem om, at der var nok så meget behov for »en høiere Almueskole «. ${ }^{20}$

Det blev dog først og fremmest Flor, der kom til at afstikke retningslinjerne for skolens udformning. Efter begivenhederne i 1842-43 havde næsten hele hans interesse samlet sig om skolesagen, og da Den Slesvigske Forening for første gang samledes den 14. august 1843, kunne han derfor forelægge en fuldt færdig skoleplan, som den 19. august 1843 blev offentliggjort i Dannevirke.

Også i denne plan henvises der til stænderforsamlingerne som det, der har vist, hvor påkrævet behovet for en højere bondeskole er. Med al respekt afvises fuldstændigt det mere realskole-prægede koncept, der lå til grund for den i 1842 oprettede skole i Rendsborg. Det er ikke en skole for de helt unge på 15-17 eller 16-18 år, man ønsker; og af de mange udmærkede fag, der læres i Rendsborg, er der ikke meget, der kan bruges i stændersalen. Med en sådan undervisning vil man kun udvikle en halvdannelse, der vil gøre bonden fremmed både for sin egen stand og for de »dannede«. Det drejer sig slet ikke om at give bonden del 
i samme slags kundskaber, som de videnskabeligt dannede har, men om at udvikle en folkelig dannelse; og derfor vil den foreslåede folkehøjskole heller ikke ligne nogen af de højskoler (dvs. højere læreanstalter), man ellers kender.

For det første skal »disciplene « ikke være drenge, men voksne. Heller ikke skal det udelukkende være bondesønner, om end der sandsynligvis vil blive flest af dem. Der skal ikke være hverken adgangs- eller afgangs-eksamen, og det skal stå enhver frit for at forlade skolen, når man ikke mener at have mere udbytte af undervisningen. Opholdet skal ikke give mindste ret til nogetsomhelst embede eller levebrød i statens tjeneste.

For det andet skal eleverne "paa en Maade tage Deel i Anstaltens Indretning og Bestyrelse«. Ganske vist skal der ansættes en forstander, der skal have næsten uindskrænket magt. Men over ham skal stå en direktion, ved siden af ham skal der være lærere, der i kraft af interessefællesskabet er hans »naturlige Consulenter og Raadgivere«; og dertil kommer, at der skal oprettes et rådgivende skoleråd, som han er forpligtet til at høre i alt vigtigt. Dette vælges af og blandt eleverne - der dog har mulighed for at indvælge lærere, hvis de ønsker det. Hvis forstanderens gerning skal lykkes, må han altså virke i forståelse med både direktionen, lærerne og - igennem skolerådet - med eleverne. Arbejdet i dette råd vil således være en overordentlig nyttig skoling til deltagelse i stænderforsamlingsarbejde eller kommunale anliggender.

For det tredje skal undervisningen ikke blot foregå som skoletimer, men i lige så høj grad ved samtaler, dels mellem eleverne og lærerne og dels mellem eleverne indbyrdes, samt ved »forelæsninger «.

For det fjerde skal disse forelæsninger ikke sigte på at bibringe videnskabelig dannelse eller bestemte kundskaber, men først og fremmest på at oplyse om elevernes stilling som borgere i staten og landets børn og i øvrigt »Det, de ellers kunde have Gavn og Glæde af at lære og erfare«. Der må altså nærmest menes, hvad vi ville forstå ved folkelige foredrag.

Hvad der ellers skal læres, kan ikke i enkeltheder angives på forhånd, thi »paa vor Høiskole skulde ikke foredrages Andet end hvad Disciplene selv erkjendte at være til deres Gavn eller Fornøielse«. Og desuden må fag og emner i nogen grad være afhængige af forstanderens og lærernes duelighed. Alligevel udkastes der en skitse af den mulige fagkreds - med understregning af, at fagene skal gribes an med folkeligt sigte. ${ }^{21}$ 
Til slut erklæres det, at der er tale om »en Underviisnings-Anstalt, hvor Discipelens daglige Følelse ikke er den nedtrykkende: der bliver lagt en Byrde paa dig! men den oplivende: der gaaer et Lys op for Dig!« Utvivlsomt vil en sådan folkehøjskole blive det »allersikkreste Værn imod al borgerlig og aandelig Undertrykkelse«.

Det er forbløffende, hvor præcist Flor her har grebet det væsentligste i Grundtvigs højskoletanker, og hvor radikalt han har draget konsekvensen af det. For så vidt som Grundtvig kunne se bort fra sin gamle $\varnothing n s k e d r ø m$ om statsh $\varnothing$ jskolen i Sor $\varnothing$, ville han ikke med rimelighed kunne beklage sig over Flors skoleplan som udtryk for sine idéer. Selv henviste han flere gange til stænderforsamlingerne som det, der nødvendiggjorde oprettelsen af en dansk $\phi \varnothing j$ skole. ${ }^{22}$ Selv gik han ind for, at højskolen skulle være for voksne og ikke, som Kold oprindelig mente, for halvvoksne. Afvisningen af adgangs- eller afgangseksamen er givetvis hentet hos ham så vel som princippet om, at højskolen ikke skal forberede til noget levebrød..$^{23}$ Kombinationen af en forstander med uindskrænket myndighed, men pligt til at høre et skoleråd, valgt af eleverne, synes at være direkte overtaget fra Bøn og Begreb ... Her påpeger Grundtvig i øvrigt selv, at den præcist svarer til den stænderforfatning, som han jo netop var så begejstret for. ${ }^{24}$ Der er blot den forskel, at skolerådets medlemmer ifølge Grundtvig »næsten Alle« skulle vælges af eleverne, mens Flor forbeholder valgretten for eleverne alene. For så vidt er han endnu mere radikal end Grundtvig. At skolestrukturen er udvidet med en direktion, kan næppe stride mod Grundtvigs idé. Og at idéen om samtalen som et væsentligt led i undervisningen stemmer med hans, behøver ingen at tvivle om, der har set, hvor tit tanken om den levende vekselvirkning dukker op hos ham.

For så vidt er der altså ingen tvivl om, at Flors skoleplan helt igennem er båret af en ægte grundtvigsk inspiration. At den også er tænkt som en bastion i den nationale kamp, kan på ingen måde diskvalificere den som grundtvigsk, specielt ikke i betragtning af, hvor voldsomme udfald mod tyskheden man finder i Grundtvigs skrifter fra disse år, og hvor stærke ord han kunne bruge om tyskheden som den dødelige fjende af dansk folkelighed. Nok var der forskel på de nationalliberales mere politiske forståelse af det nationale og Grundtvigs folkelige; men her, hvor den folkelige undertrykkelse just tog form af en national undertrykkelse, lod det sig i praksis ikke gøre at skelne.

Ifølge sagens natur kan det ikke undre, at Flors skoleplan minder mere om den »medborgerskole«, Grundtvig oprindelig forestillede sig, 
end om den »vækkelsesskole«, der efterhånden voksede frem, og som Kold bærer et hovedansvar for; men Flors plan står dog som en advarsel mod at skelne for skarpt i den retning. Navnlig slutningsordene om den oplivende følelse, der skal hænge sammen med oplysningen, minder meget om Kolds synspunkter.

På mødet den 14. august 1843 blev det efter »en levende Discussion « vedtaget, at grundtrækkene i Flors plan skulle tages til følge ved oprettelsen af folkeh $\varnothing j$ skolen. Men planen blev ikke alle steder modtaget med udelt begejstring. H. N. Clausen, der jo spillede en væsentlig rolle m.h.t. sikringen af skolens $\emptyset$ konomi, var på egne og adskilligt fleres vegne dybt skeptisk. Han $\emptyset$ nskede netop en kundskabsskole for unge på 15-18 år og et undervisningsforløb, der strakte sig over to år, og han var helt afvisende over for tanken om et skoleråd, som han opfattede som udtryk for »misforstaaet Liberalitet«. Og Nissen og Skau skrev til Flor om en dyb og generel skepsis over for planen. ${ }^{25}$

Man tabte dog ikke modet. Sidst i september 1843 rejste Flor til København, og sidst i oktober fulgte Den Slesvigske Forenings formand Hans Nissen, kassereren Nis Steffensen og sekretæren Laurids Skau efter. Ved forenede anstrengelser lykkedes det at overbevise de $k \varnothing$ benhavnske nationalliberale om, at de burde overlade ledelsen af skoleplanerne til Flor og til nordslesvigerne selv, mens københavnerne burde indtage en tilbagetrædende stilling som $\varnothing$ konomiske bagmænd. Det var klart, at dette ville betyde en folkehøjskole og ikke en realskole. ${ }^{26}$

Helt opgav københavnerne dog ikke deres indvendinger. Den 6. december 1843 skrev Clausen til Flor, at en omarbejdelse af skoleplanen ville være særdeles velkommen og muligvis overflødiggøre visse betingelser, som ellers ville blive stillet. ${ }^{27}$

Dette $\varnothing$ nske var allerede ved at være opfyldt. Det fremgår af breve fra Flor fra 2. og 7. december og fra Skau fra 3. december, at sidstnævnte efter Flors ordre samme dag ville indsende en af Flor udarbejdet skoleplan til kongen sammen med en ansøgning om tilladelse til at oprette skolen. Da Flor tilbød kongens kabinetssekretær at udsætte offentliggørelsen, indtil kongens afgørelse forelå, kan der ikke være tale om hans oprindelige plan fra den 14. august, der jo var blevet offentliggjort den 19. august. Der er altså tale om en omarbejdelse eller en ny plan. Efter al sandsynlighed er den ny plan også blevet tilsendt Clausen og hans fæller i København. ${ }^{28}$ 
Det trak ud, inden man fik kongens godkendelse; hvilket dog ikke hindrede, at man målbevidst fortsatte forberedelserne. Den 3. december 1843 foreslog Skau Flor at ansætte cand.theol. Johan Wegener som forstander, og den 19. december havde Wegener fået tilbudet. Den 16. december købte Nissen, Steffensen og Skau en gård i Rødding, der skulle bruges som skolebygning. Den 2. januar 1844 kom det officielle tilsagn fra Syvstjernen om $\varnothing$ konomisk st $\varnothing t t e$ til skolen. Den 12. februar valgtes der en direktion på 7 medlemmer med Flor som formand. Den 14. marts sagde Wegener efter lange overvejelser ja til at blive forstander. Den 17. juni kom - langt om længe - kongens tilladelse til skolens oprettelse, og den 20. juli kunne direktionen offentliggøre den skoleplan, der var indsendt til kongen, i Dannevirke. ${ }^{29}$

Sammenligner man den med Flors oprindelige, er der tale om betydelige forskelle. Ganske vist er formålsparagraffen helt i den første plans ånd. ${ }^{30}$ Men der arbejdes nu med to afdelinger af skolen, én for unge på 16-18 år og én for voksne. Der er afgørende forskel på reglerne for den ene og den anden afdeling. De yngre elever skal som hovedregel komme til 1. november eller 1. maj, og et fuldstændigt kursus varer to år. Der opstilles ikke blot en fagplan, men endog en timeplan. Der er mødepligt til de enkelte timer, og der ofres en hel del overvejelser på disciplinære forhold.

For de ældres vedkommende er der tale om en langt st $\varnothing$ rre frihed. De kan komme og gå til timerne efter behag, idet der regnes med, at lærernes og elevernes gensidige interesse for oplysningsarbejdet er den bedste regulator af elevernes opførsel så vel fagligt som disciplinært. Idet fagkredsen i et vist omfang dækker sig med de yngre elevers, regnes der dog i større omfang med gæstelærere, herunder også duelige og talentfulde videnskabsmænd. Især vil man satse på forelæsninger, der sigter på at bibringe tilhørerne en rigtig og tydelig forestilling om deres borgerlige forhold, herunder de forskellige samfundsklassers forhold til hinanden. Det bemærkes, at enkelte af de yngre elever, for så vidt som deres opførsel berettiger dem til en plads mellem voksne og selvstændige mennesker, kan få adgang til at overvære sådanne forelæsninger. Den gamle kongstanke om skoleråd er fastholdt for de ældre elevers vedkommende.

Man kunne måske sige, at Flor med denne skoleplan har imødekommet Clausens kritik ved at dele skolen i to afdelinger. De yngres afdeling, der i et vist omfang kan minde om en realskole, må formodes at stemme væsentligt bedre med Clausens idéer end de ældres. Man reg- 
nede vistnok med, at den ville blive den mest søgte. Dette sammenholdt med, at Syvstjernens folk nu engang var gået ind på i højere grad at overlade initiativet til sønderjyderne selv, har formodentlig gjort planen spiselig for dem. Til gengæld har Flor så fulgt sit eget hoved ved planlægningen af de ældres afdeling, der med sin vidtstrakte frihed i langt højere grad virkeliggør hans og Grundtvigs tanker. ${ }^{31}$

Skolen åbnedes den 7. november 1844. Forstanderen, Johan Wegener, var glødende national og skandinavist og havde med lidenskabeligt engagement fulgt den bitre nationalitetskamp i Sønderjylland. Han havde også været begejstret for Flors oprindelige skoleplan, der jo var klart grundtvigsk.

Måske er der en vis tvetydighed over hans holdning. Det synes at fremgå af hans brev til Flor af 19. december 1843, hvori det hedder:

- Med Hensyn til den nye Plan for Skolen, da finder jeg, at den staaer tilbage for den ældre, som i sin Tid stod i Dannevirke. Denne ældre Plan syntes mig udsprungen af en begeistret Nationalaand, der havde Mod til at vove noget Nyt; alle Led vare nøie forbundne, af een St $\varnothing$ bning; man havde fors $\varnothing \mathrm{gt}$ at gjøre det gamle Maskineri i Skolevæsenet til en virkelig Organisation; vel syntes mig paa enkelte Steder at fremtræde en vis Naivitet samt Probering paa en Tilsætning af den grundtvigske Kraftsuppe; men jo nøiere jeg betragtede Planen, syntes dette mig kun noget blot tilfældigt, og Substansen at være af den solideste Beskaffenhed. ${ }^{32}$

Udgiveren af Højskolens Ungdomstid i Breve, Roar Skovmand, identificerer »den nye Plan « som Flors plan af 14 . august 1843, mens den ældre bestemmes som Den Slesvigske Forenings proklamation af 12. juni samme år. Dette kan imidlertid ikke være rigtigt. Proklamationen af 12. juni er ikke så detaljeret, at den kan kaldes en skoleplan, og det giver ingen mening at sammenligne den med Flors. Tilmed skriver Wegener $i$ indledningen til brevet, at han just har modtaget den ny plan fra Hans Nissen og Laurids Skau. Der må derfor være tale om den plan, som disse to havde med på Københavns-rejsen i efteråret 1843, men som ikke blev offentliggjort før 20. juli 1844.

Det er klart, at Wegeners ord om en »Tilsætning af den grundtvigske Kraftsuppe «ikke er ment som en ros. På den anden side er det klart, at han nærede den største beundring for Grundtvig. I et brev til ham af 26. november 1844 betegner han ham som en »Fader og Ven«, som »en 
af Nordens største Aander og som »Danmarks første Nationalkjæmpe $\ll .{ }^{33} \mathrm{Og}$ når dertil lægges, at Flor som formand for skolens direktion og som dens åndelige bagmand $\mathrm{i}$ lige så $h \varnothing j$ grad måtte tegne firmaet som Wegener, kan der næppe være tvivl om skolens forhold til det grundtvigske.

Som bekendt varede Wegeners forstandertid kun fem måneder. Han fratrådte til maj 1845, hvorefter Flor selv overtog ledelsen. Hans forstandertid var næppe nogen ubetinget succes, og efter halvandet års forløb fratrådte han - idet han dog blev ved at følge skolens skæbne med st $\varnothing$ rste interesse, ofte aflagde bes $\emptyset \mathrm{g}$ der og som formand for direktion og senere bestyrelse $\emptyset$ vede afgørende indflydelse på dens forhold indtil dens lukning.

Hans linje har været klar nok - hvilket fremgår af den beretning, han udsendte i 1846. Idet han her afviser tanken om eksamen, skriver han:

Det Vigtigste ved Underviisningen paa vor Høiskole er ikke de positive Kundskaber og Færdigheder, som vi søge at bibringe Eleverne, men snarere det hele aandelige Liv, som bliver vakt og næret hos dem ... ${ }^{34}$

Den 20. juni skriver han til Grundtvig om Frederik Helveg som sin mulige efterfølger og diskuterer her, om Helveg, der stammede fra en holstensk familie og selv var født i Holsten, måske var lige så meget tysk som dansk. Men han understreger,

at Spørgsmaalet ikke blot er overfladisk om Dansk eller Tysk, men om det aandelige, altsaa ogsaa hjertelige, Livs Sejer eller Død her i Slesvig, og at Aanden, saa vidt jeg kan skjønne, hos Helweg er stærk og klar nok til at see, at disse to Ting her falde sammen. I Grunden er det altsaa kun Aandens Liv jeg selv fægter for, i det jeg strider for Danskheden og Skandinavismen. ${ }^{35}$

Det er ikke uden grund, at Vilhelm Andersen kalder Rødding under Flors ledelse »højgrundtvigsk - et udtryk, der tiltrædes af Roar Skovmand. ${ }^{36}$

Flor afløstes som forstander af Helveg, der virkede fra november 1846 til april 1848, da han måtte standse på grund af krigen. For hans vedkommende må der især henvises til Søren Jensens redegørelse i Vartovbogen $1995 .{ }^{37}$ Søren Jensen har utvivlsomt ret i, at Helveg i 
urimelig grad er blevet ignoreret $\mathrm{i}$ behandlingerne af $\mathrm{R} \varnothing \mathrm{dding} \mathrm{H} \varnothing \mathrm{j}$ skoles historie. Af de tre første forstandere var det utvivlsomt ham, der havde bedst tag på det praktiske højskolearbejde, og det var da også ydre begivenheder, der tvang ham væk, ikke et personligt nederlag som skoleleder.

Et andet forhold, der ligeledes tydeligt fremgår af Søren Jensens fremstilling, er Helvegs discipelforhold til Grundtvig. Skønt han stammede fra en holstensk familie og selv var født i Holsten, oplevede han omkring 1840, hvad Søren Jensen kalder »en regulær dansk-grundtvigsk vækkelse«, og herefter blev han glødende dansk patriot. Efter meget indviklede forhandlinger blev han som nævnt forstander i november 1846, idet Flor dog blev på skolen vinteren over. Egentlig skyldtes dette vel Flors mistillid til den unge holstener; men denne mistillid blev i løbet af vinteren til et varmt venskab, der varede lige til Flors død i 1875.

Det viste sig da også, at Helveg helt og fuldt gik ind for Flors folkeligt dannende linje. Som eksempel kan nævnes hans kommentarer til en betænkning om anlæggelse af højere skoler på landet, der var afgivet af en komité under stænderforsamlingen i Viborg. ${ }^{38}$ Han glæder sig her over, at sådanne skoler efter komiteens mening skal sigte på den almindelige humane dannelse, og over, at Rødding omtales som et muligt forbillede. Han fortsætter:

Med Hensyn til Skolen i Rødding er altsaa derved den Erkjendelse udtalt, at den er noget mere end blot et Nødværge imod slesvigholsteenske Partibestræbelser og Fortydskningens Fremtrængen.

Skolens formål er ikke blot af værgende, men opelskende, nemlig for den dannelse, som for folket og ikke blot for den enkelte i folket er den højeste. Han advarer mod statsstøtte og dermed sammenhængende statskontrol, der sandsynligvis vil medføre krav om eksamen, og han erklærer, »at jeg heller vendte Rødding Skole Ryggen end jeg taalte, der paanødtes den og mig en Examen«. Mod slutningen af sin redegørelse skriver han:

Det er ingenlunde paa Tydskhedens Fremtrængen eller Standsning at Nationens Fremtidsskjæbne beroer, men meget mere paa om Folkeaanden bliver vakt eller ikke. 
Helveg viste sig altså som en værdig efterfølger af Flor. Men hans virke ved skolen blev kort. Da krigen kom i 1848, måtte den standse, og først i november 1850 kunne den åbnes igen. Helveg var i mellemtiden blevet præst, og som ny forstander ansattes Sofus Høgsbro, der var anbefalet af både Grundtvig og H. N. Clausen. ${ }^{39}$ Høgsbros forhold til Grundtvig var ret ejendommeligt. Allerede i sin ungdom var han blevet påvirket $\mathrm{i}$ grundtvigsk retning af Ludvig Chr. Müller, der var præst og lærer ved latinskolen i Ribe. I studietiden indførtes han gennem sønnerne Johan og Svend i det grundtvigske hjem. Han vedblev at komme der jævnligt studietiden igennem, og det nære forhold fortsatte ikke alene $i$ hans forstandertid, men især i perioden fra han i 1858 blev folketingsmand og til Grundtvigs død. Trods næsten 40 års aldersforskel blev han således en personlig, om end ingenlunde ukritisk ven af Grundtvig. Teologisk set blev han aldrig grundtvigianer, hvorimod han i kirkepolitikken udmærket kunne arbejde for den grundtvigske frihedslinje. Politisk set var han ofte uenig med Grundtvig, især som ung. Senere nærmede deres synspunkter sig stærkt til hinanden, mens Høgsbros og sønnernes skiltes. Folkeligt og pædagogisk set var han hele tiden fuldt ud på Grundtvigs linje. ${ }^{40} \mathrm{Og}$ netop derved demonstrerede han det for eftertiden så åbenbare forhold, at grundtvigianismen var ved at udvikle sig til en kirkelig-folkelig dobbeltbevægelse, hvor det meget vel var muligt at være en fuldtro Grundtvig-discipel på det ene område uden at være særlig engageret på det andet.

Da Høgsbro i 1853 udsendte sin første beretning om Rødding Højskole, erklærede han uden forbehold, at »Den Tanke, som ligger til Grund for Rødding Folkehøjskole, er først udtalt af Pastor N. F. S. Grundtvig i flere Smaaskrifter fra 1836 til $40 . \varkappa^{41}$ Det er altså netop Grundtvigs oprindelige højskolesyn, han bekender sig til. Roar Skovmand refererer det på den måde, at Høgsbro åbent erklærede, at det var Grundtvigs Sorøtanke, der lå til grund for Røddings arbejde. Og Skovmand fortsætter: »Rødding Højskole blev forsaavidt Danmarks første grundtvigske Højskole «. ${ }^{42}$ - Igen må man dog advare mod at skelne for skarpt mellem »medborgerskolen« og »vækkelsesskolen«. Det er karakteristisk, at Høgsbro i sin beretning kan skrive: »Overhovedet er det jo ikke saameget Kundskabsmassen som Aandsopvækkelsen, Højskolen lægger an paa ${ }^{43}$

Det skulle imidlertid ikke lykkes Høgsbro at sætte sin linje igennem uden hårde kampe. Det viste sig især $\mathrm{i}$ striden med den dygtige og populære landbrugslærer Edvard Thomsen. Denne mente, at landbrugs- 
fagene skulle have så fremtrædende en plads i skolens arbejde, at den ville begynde at ligne en landbrugsskole. Dette var særlig betydningsfuldt, fordi han støttedes af en stor del af skolens bagland. Nu efter treårskrigen var danskheden sikret, mente man, og så måtte skolens vigtigste opgave være landbrugsfaglig dygtiggørelse. Men Høgsbro gik ikke på akkord med det, han anså for højskolens opgave. Han ønskede at fastholde skolen i den ånd, Flor havde nedlagt i den. Efter hans mening var Thomsens indflydelse ligefrem fjendtlig mod skolens ånd og plan, og han erklærede, at Thomsen »åbent og hemmelig « arbejdede på at give skolen en retning, der var stik modsat den, den egentlig skulle have.

På en måde var striden en genoptagelse i voldsomt skærpet form af den uenighed, der allerede i Flors tid havde foreligget mellem ham og den tidligere Rødding-lærer, dr. C. M. Poulsen, der også ønskede, at den faglige uddannelse skulle komme i første række. Ikke desto mindre tog Flor selv - til Høgsbros bitre skuffelse - Thomsens parti imod Høgsbro. Det samme gjorde i $\varnothing$ vrigt de tidligere forstandere Helveg og Wegener ligesom en lang række andre af skolens gamle venner.

Striden rasede gennem flere år og resulterede i 1855 i en ny styringsstruktur for skolen, hvorved der skulle udnævnes et selvsupplerende råd af tre såkaldte tillidsmænd med ret til at udpege og afsætte medlemmerne af bestyrelsen, mens den tidligere $\varnothing$ verste myndighed, generalforsamlingen i Den slesvigske Forening (der i 1852 havde skiftet navn til Rødding Højskoleforening) fik sin kompetence reduceret til praktisk talt intet. Nedsættelsen af dette råd gav i sig selv anledning til nye stridigheder - også mellem Grundtvig og Flor - indtil det i 1856 blev til virkelighed med Grundtvig, Knud L. Knudsen og H. A. Krüger som medlemmer. Stridens højdepunkt nåedes i 1856, da Høgsbro i frustration opsagde sin stilling. Dette $\emptyset$ nskede bestyrelsen dog ikke at tage ansvaret for, og det lykkedes derfor i største hast at skaffe Thomsen en stilling som vejkondukt $\varnothing \mathrm{r}$ i hertugdømmerne med bolig i Flensborg, hvorefter han forlod Rødding. Så lovede Høgsbro tøvende at blive som forstander. ${ }^{44}$

For en eftertid kan det være vanskeligt nok at se til bunds i denne strid, hvor personlige, pædagogiske og ideologiske hensyn krydsedes på flere forskellige planer. Det må naturligvis virke forvirrende, at $\mathrm{H} \emptyset g$ gbro angiveligt $\varnothing$ nskede at fastholde Flors linje, mens Flor selv tog parti imod ham. Ikke mindre forvirrende bliver billedet ved, at Flors »aandelige Mester og Herre « Grundtvig uden forbehold støttede Høgsbro imod Flor 
- hvilket dog ikke forhindrede ham i som tillidsmand at sætte Flor og Helveg ind $\mathrm{i}$ bestyrelsen - hvilket efter Høgsbros udsagn var den direkte anledning til, at han opsagde sin stilling. Og helt grotesk synes billedet at blive, når Høgsbro oplyser, at hans modstandere netop havde ønsket disse to mænd ind $\mathrm{i}$ bestyrelsen »som Værn mod Grundtvigianismens Magt og som Borgen for Højskolens Fortsættelse efter sin oprindelige Plan ${ }^{45}$

Hvad angår den sidste tilsyneladende selvmodsigelse må det tages i betragtning, at den tidligere omtalte udvikling af grundtvigianismen til en kirkelig-folkelig dobbeltbevægelse endnu kun var i sin vorden. Grundtvigianisme opfattedes på den tid først og fremmest som en religiøs og kirkelig, evt. som en teologisk bestemmelse. Det var først i 1861, Grundtvig citerede patriarken Jakobs ord: Se, jeg er blevet til to hære $!^{46}$ Når Flor og Helveg kunne ses som et værn mod grundtvigianismen, må det derfor forstås som et værn imod eventuelle fors $\emptyset \mathrm{g}$ på at gøre Rødding til en kristeligt vækkende skole. Om Grundtvig har set valget af dem i dette perspektiv, må stå hen; men principielt er der ikke noget i vejen for det.

Striden mellem Thomsen og Høgsbro drejede sig i øvrigt om adskillige andre forhold end skolens pædagogiske og ideologiske linje - f.eks. om disciplinære forhold og om skolens eventuelle flytning til Gråsten. Den ideologisk-pædagogiske konflikt var trods alt ikke mere klar, end at Thomsen selv kunne mene, at han meget vel forstod Flors mening med skolen, og at det var uberettiget at beskylde ham for at ville omdanne skolen til en landvæsensskole. Derimod er det klart, at der var regulære kompetencestridigheder mellem Thomsen, der var inspektør for elevhuset og i $\varnothing$ vrigt havde været lærer på Rødding allerede før treårskrigen, og Høgsbro. Og dertil kom, at de to parter rent personligt nok havde svært ved at omgås hinanden. Høgsbro kunne være meget usmidig, mens Thomsen havde et meget vindende væsen. Dette har givetvis spillet en afgørende rolle i forholdet til Flor og Helveg. Ægidius betegner forholdet mellem Flor og Thomsen som »noget i retning af et fader-s $\varnothing$-forhold «, og da Thomsen tilmed fra første færd havde gjort sig store anstrengelser for at give både Flor og Helveg sin fremstilling af striden, måtte de begge komme til at se den fra hans side. Der er næppe tvivl om, at de personlige følelser i den givne situation har sløret deres blik for, at det faktisk var Høgsbro, der på sin egen stejle og kantede måde repræsenterede den grundtvigske opfattelse af højskolens opgave. ${ }^{47}$ 
På længere sigt var der ingen tvivl om deres holdning. Det viste sig, da højskolen omkring 1860 blev udsat for meget hårde angreb - bl.a. fra dens gamle ven og medstrider Dannevirke - og i vid udstrækning med Thomsenske argumenter. Da rykkede både Flor og Helveg ud til eftertrykkeligt forsvar for både skolen og Høgsbro. I den forbindelse skrev Flor i 1860:

Rødding Høiskole har nu bestaaet i over 15 Aar. I denne Tid er der i alt Vaesenligt ikke gjort den mindste Forandring, enten i det Maal, vi tilsigte og fra første Begyndelse have tilsigtet med vor Underviisning og Opdragelse, eller i de Midler, vi anvende for at naae dette Maal. ${ }^{48}$

At Høgsbro fastholdt den folkelige linje viste sig også, da det straks efter Thomsen-striden trak op til konflikt mellem ham og hans gode ven, Jens Lassen Knudsen, der siden 1852 havde været lærer på skolen. Knudsen var i en ganske anden grad end Høgsbro grundtvigianer i kirkelig forstand og mente, at skolen skulle have et kristeligt vækkende sigte. Egentlig betragtede han Kolds vækkelsesskole som idealet. I striden med Thomsen st $\varnothing t t e d e$ han naturligt nok Høgsbro; men da den sag var afklaret, kom modsætningerne stærkere frem. Fra visse sider var der endog $\emptyset$ nsker om, at han skulle overtage Høgsbros plads som forstander. I september 1856 prøvede han at gøre Høgsbro begribeligt, at Rødding burde »være bestemt grundtvigsk «, dvs. arbejde mere direkte for en folkelig og kristelig væk-kelse af eleverne i grundtvigsk ånd. Han gjorde indsigelse mod, at $\mathrm{H} \emptyset \mathrm{gsbro}$ optog hvem som helst på skolen, og mente, den burde begrænse sig til elever, hvis forældre i forvejen var indforståede med dens holdninger. Han henviste til Grundtvigs højskole Marielyst - som i øvrigt først åbnede til november samme år, og hvis praksis han derfor ikke kunne have meget kendskab til. Ironisk nok opfordrede Høgsbros gamle modstander Thomsen ham ivrigt til at stå fast over for Knudsen. ${ }^{49}$ De repræsenterede jo netop modsatte holdninger - af hvilke dog ingen faldt sammen med Høgsbros. Og Høgsbro stod fast. Ganske vist ville han ikke afskedige Knudsen - der efter besøg på Kolds højskole blev så grebet af den, at han i 1862 lod sig ansætte som lærer ved den. Men Høgsbros linje var den folkelige. Allerede i beretningen fra 1853 skrev han: »Da Højskolen maa betragtes som en folkelig og ikke som en kirkelig Opdragelsesanstalt, har den egentlige Religionsundervisning aldrig haft Plads paa den uden i 
historisk Form« - hvorved der jo principielt var taget afstand fra vækkelsesskolen. Og derved kom han »imellem 2 Ilde«, som Harald Boisen skrev i 1856. I 1861 skrev Høgsbro til Flor: »Det er i det hele mærkeligt i hvilken Grad Folk enten vil have Skolen udelukkende grundtvigiansk eller landøkonomisk og examensmæssig $~^{50}{ }^{50}$ Der er ikke tale om at ændre linjen; men et vist mismod er tydeligt; og da han tilmed var under hårde angreb, fordi han havde ladet sig vælge til folketinget, opgav han i 1862 sin forstanderstilling og flyttede til København - hvor han i øvrigt gik en strålende politisk karriere i møde.

Hans afløser blev Ludvig Schrøder, hvis gerning først og fremmest kom til at falde i Askov. Der skal derfor ikke gås nærmere ind på den her. Dog det kan måske have sin interesse at nævne, at Flor i 1865 kunne skrive, at ingen af forstanderne og lærerne på Rødding havde været mere enige med ham om skolens mål og den hensigtsmæssigste vej dertil end Schrøder. ${ }^{51}$

Jeg ser derfor ikke rettere, end at det vil være en fuldstændig misforstålse at tro, at Rødding ikke skulle have været en grundtvigsk skole. Flors opfattelse af højskolens opgave er tydelig nok, og bortset fra, at han blev ved at $\varnothing v e$ afgørende indflydelse på skolen, så længe den virkede, så har de skiftende forstandere dog hver på sin måde søgt at følge den samme linje. Der kan derfor ikke være tvivl om, at Rødding fortjener navn af Danmarks første grundtvigske folkeh $\varnothing$ jskole.

Derimod kan man nok undre sig, hvis man ser på Grundtvigs forhold til Rødding. Det er unægtelig tvetydigt.

Selve oprettelsen af $h \varnothing j$ skolen hilste han med glæde. Hans hilsen fra Skamlingsbanken den 4. juli 1844 kan som nævnt kun forstås som en uforbeholden anerkendelse af skolen som en virkeliggørelse af hans egne drømme - og som et tilsagn om ubegrænset st $\varnothing t t e$.

Samme år den 26. november skrev Wegener som nævnt et brev til ham med en udførlig beretning om forholdene på højskolen. Han fremstillede det her, som om det netop var skolens mål at realisere Grundtvigs tanker. Og brevet slutter: »- kom selv engang, danske Hædersmand! kom, viis os, hvorledes vi skulle bære os ad; lær os at opdrage Deres nyfødte Barn! «. ${ }^{52}$ Men Grundtvig kom ikke.

I foråret 1846, da Flor var forstander, traf han Grundtvig i København. Han bad ham her om at besøge Rødding og blive der en 8-14 dage. Grundtvig sagde, at han havde lyst til det, og lovede at skrive, når det kunne lade sig gøre. I juni skrev Flor til ham og mindede ham om indbydelsen. Han skrev bl.a., at »Mange, baade Skolens afgangne Elever og 
ældre Mænd, vente med megen Længsel, at dette skal skee, da de i saa Fald ville i den tid indlogere sig her i Rødding. « Flor forestillede sig

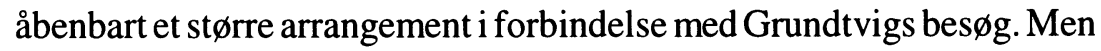
Grundtvig kom ikke.

I 1845 var Grundtvigs ven Peter Rørdam i Sønderjylland, hvor han traf Flor og blev meget interesseret i, hvad der skete i Rødding. Til Grundtvig skrev han samme år, at »det er Deres Ideer om en Bondeskole, som der er førte igjennem, i deres Begyndelse«. I juni 1847 skrev han igen til Grundtvig og foreslog en fælles rejse derover. Han forelagde forskellige mulige tidspunkter, ligesom han skitserede en rejseplan. Det hele var lagt til rette. Men Grundtvig gav et svar, som fortjener at blive citeret. Han skriver:

De skal ogsaa have Tak for deres Forslag til en Rødding-Reise, men derpaa har jeg dog for Øieblikket intet Mod, da jeg, Gud skee Lov! befinder mig vel, er i Arbeide og veed ikke, hvortil Reisen skulde nytte, eller hvem jeg skulde faae til at besørge Embedet i min Fraværelse.

Han $\emptyset$ nsker dog Rørdam lykkelig rejse og hører gerne nærmere om, hvad han har oplevet! ${ }^{53}$

12 år efter Røddings oprettelse, nemlig i talen ved indvielsen af Marielyst Højskole 3. november 1856, ignorerede han den fuldstændigt. Han hilste nu Marielyst som selve opfyldelsen af, hvad han havde håbet på og længtes efter i mangfoldige år; og han fortsatte:

- thi da det gik saaledes i Langdrag med den folkelige Høiskole ... gik saa forskrækkelig i Langdrag, at jeg ikke blot blev graa, men fyldte de syv Gange ti Aar, og syndes lige langt fra Maalet, da græmmede det mig visselig ... ${ }^{54}$

Grundtvig fyldte 70 i 1853, og Marielyst blev som sagt indviet i 1856. Det ser med andre ord ud som en regulær desavouering af Rødding. Det er ikke mærkeligt, at J. L. Knudsen i 1862 kan tale om Grundtvigs ligegyldighed over for Rødding. ${ }^{55}$

Der er dog også andre signaler fra hans side. Som sagt godkendte han fuldt ud planen i 1844 . Ved den nordiske højtid i januar 1847 var han hovedtaler, og i talen om Nordens historiske minder sagde han: 
Og hvilket lykkeligere Varsel for Kæmpeaandens og de historiske Minders folkelige Seier, ved Ungdommens Hielp ... hvilket lykkeligere Varsel kan nævnes, end hvad iaften ei maa forties: Kiendsgerningen, at den unge Mand, som her ifjor med Liv og Kraft talde Aandens og Mindernes Sag (dvs. Helveg), han staaer allerede iaar og taler samme Sag midt i Folkets Kreds, paa den første folkelige Høiskole i Norden, staaer og bygger paa et uundværligt Dannevirke, hvortil hele Norden med mig maa ønske Lykke, Held og Velsignelse. ${ }^{56}$

I 1848 fik Helveg ham til at skrive en sang til en sørgefest, man ville holde på skolen i anledning af Christian VIII's død. ${ }^{57}$ Da skolen i 1850 åbnedes igen efter krigen, aftrykte han hele $\mathrm{H} \varnothing$ gsbros åbningstale i sit tidsskrift Danskeren - hvor han ellers selv skrev det meste af indholdet. ${ }^{58}$ I 1856 gik han som nævnt med til at lade sig vælge som »tillidsmand «med følgende, lidt ejendommelige motivering:

Vist nok er jeg kun lidet skikket til at gavne Høiskolen uden ved maaske at kunne afvende dens Skade, men dette anseer jeg, efter Omstændighederne vigtigt nok, saa jeg ikke bortskyder den mig viste Tillid. $^{59}$

Ved juletid 1863 bevidner Flor i et brev til Schrøder, at både Grundtvig »og hans meget ivrige Hustru« var i høj grad tilfredse med skolens virksomhed. ${ }^{60}$ Og i 1864 henviser Grundtvig i sin »Budstikke i Højnorden « til Rødding, Skamlingsbanken og Slien som de steder, der blev talt dansk, så selv tyskeren til sit raseri måtte høre på det. ${ }^{61}$

Alt i alt må man nok regne med, at Grundtvig slet ikke har $\emptyset$ nsket at desavouere Rødding. Han har i og for sig vedkendt sig den, men blot haft et ret fjernt forhold til den. Det skyldes nok først og fremmest, at han havde så svært ved at opgive drømmen om Sorø. Den havde dog været så nær ved at blive til virkelighed. ${ }^{62}$ Det er karakteristisk, at talen på Marielyst i 1856 i direkte tillknytning til det ovenfor s. 85 anførte citat fortsætter:

- og maatte græmme mig saameget mere, som det een Gang paa et hængende Haar var lykkedes mig at faa den Sag i ønskelig Gang, men var saa dog glippet, som det syndes for bestandig. 
Så meget betød Sorø-højskolen for ham, at han ikke helt var i stand til at se mulighederne i de højskoler, der kom. Ganske vist sagde han i $1848 \mathrm{i}$ en rigsdagstale, at »lykkedes det først at faae een saadan Skole istand, saa vilde de snart opstaae paa mange Steder trindt om i Landet « ${ }^{63}$ Men selv her så han dem dog kun som en mulig følge af den ene skole, som var hans store $\emptyset$ nskedrøm, og som hele tiden dukkede op, når han skulle forklare sine idéer: Den statsdrevne folkehøjskole i Sorø. Hans ven Ingemann var - som det skulle vise sig - mere realistisk, idet han allerede i 1849 erklærede: »Jeg mener for Resten med Flor, at flere smaa Røddinger ere de bedste højere Folkeskoler. ${ }^{64}$

Og efterhånden måtte Grundtvig også bekvemme sig til at tage denne tanke alvorligt. Den 7. november 1869 blev der i København holdt en stor fest i anledning af 25-året for Røddings oprettelse og for Flor. Ved den lejlighed, hvor Grundtvig selv var til stede, citerede Carl Ploug ham for at have kaldt Rødding »Moder til alle de Højskoler, som nu næsten bedækker vort Land og har forplantet sig til Sverrig og Norge. ${ }^{65}$ Kort efter afbrød Grundtvig Ploug med en supplerende tilføjelse til hans tale; men mod dette citat gjorde han ingen indsigelse.

Virkeligheden er alle tings prøve, og Rødding-modellen havde vist sig bærekraftig. At Grundtvig havde haft så svært ved at se, at det var ad den vej, hans tanker om folkelig opdragelse skulle virkeliggøres, var ikke Røddings fejl.

Noter

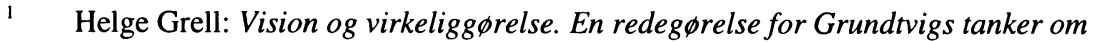
folkelig oplysning og en folkelig højskole og for forsфget på at virkeliggøre dem (Rygtitel: Vision og realisering af Grundtvig. - Center for Grundtvig-studier, Århus, 1998).

Grell, anf. skr., s. 33-34.

3 Ernst J. Borup og Frederik Schrøder: Haandbog i N.F.S. Grundtvigs Skrifter, bind I (1929). - Grundtvigs tale (»Skov-Hornets Klang mellem Skamlings-Bankerne«) er aftrykt i uddrag s. 134-140. I sin helhed findes den i Grundtvigs Udvalgte Skrifter ved Holger Begtrup, IX (København 1909), s. 18-36.

$4 \quad$ Knud Eyvin Bugge: Skolen for Livet (København 1965), s. 297 og note 36. 
»Skolen for Livet «, N.F.S.Grundtvig: Varker i Udvalg, red. Georg Christensen og Hal Koch (herefter VU), IV (1943), s. 225, 226; jfr. »Bøn og Begreb om en dansk Høiskole i Soer«, sts., s. 390-391.

Der tænkes her især på Grundtvigs udtalelser om Kold på vennemøderne 1865 og 1866, se Kr. Køster og N.Lindberg: Det kirkelige Vennemøde $i$ Kjøbenhavn, den 7 de og 8de September 1865 (København 1865), s. 84, og Kristian Køster: Det kirkelige Vennem $\phi$ de i Kjøbenhavn, den 10de og 11te September 1866 (København 1866), s. 45. - Men allerede flere år før skulle Grundtvig have kaldt Kolds skole for den allerbedste af alle vore »folkeskoler« og fremhævet den på Røddings og Hindholms bekostning (Jeppe Tang til Kold 23.02.1855, Højskolens Ungdomstid i Breve, udg. af Roar Skovmand (København 1960), II, s. 198). Ifølge Ludvig Schrøder skulle han have kaldt den den mest folkelige skole (Schrøder til Charlotte Wagner 13.12.1861, sts., s. 21-22).

Dannevirke, 06.02.1841 (s. 252). - »Nordslesvigeren« var muligvis Peter Hiort Lorenzen, se herom H. Rosendal: Nogle Bidrag til Rødding Højskoles Historie (Kolding 1894), s. 10, Jens Peter Ægidius: Christian Flor (Odense 1994), s. 194195 og Gunhild Nissen: Udfordringer til Højskolen (Odense 1994), s. 28, jfr. s. 361 , note 32 .

Anmeldelsen i Dannevirke, 07.11 .1840 (s. 151). Brevet til Flor: P. Lauridsen: $D a$ Sønderjylland vaagnede, I (2. oplag, København 1919), s. 102.

Utrykt brev til J. P. Mynster fra marts 1828, citeret i Ægidius: Christian Flor, s. 67, jfr. kapitlet »Den slesvigske Sag«, s. 68-88. Sønderjyske Årbøger 1992 (Vojens 1992), s. 129.

Da Sønderjylland vaagnede, VI (1918), s. 52, 63 (:Generallissimus«); VIII (1922), s. 13.

Ludvig Schrøder i Højskolebladet, 1896, sp. 488. Jfr. Ægidius, Christian Flor, s. 88-96.

Da Sфnderjylland vaagnede, I, s.108, jfr. Ægidius, Christian Flor, s. 93-94. - Anmeldelsen blev omsider trykt i Brage og Idun, I (København 1839), s. 176-230, og i let ændret version som et selvstændigt skrift med titlen Kort Fremstilling af N.F.S.Grundtvigs mythologiske og historiske Betragtningsmåde (København 1865). - Vedr. sammenligningen med Kant, Schelling og Hegel se Brage og Idun, I, s. 177, Kort Fremstilling ..., forordet (s. 3) og s. 5-6. - Der hersker en vis uklarhed om, hvornår anmeldelsen er skrevet. Ifølge Fgidius (Christian Flor, s. 93, 362), der støtter sig på et utrykt brev fra Flor til Grundtvig af 25.03.1837, er den skrevet i 1837. I Brage og Idun, der kom i 1839, skriver Flor selv, at det nu er 6 år siden, Nordens Mythologi udkom (s. 176). Dette indicerer, at anmeldelsen er skrevet i 1838 - hvilket meget vel er muligt, uanset at den først er trykt 1839. Men i Kort Fremstilling ..., forordet (s. 3) skriver Flor, at den er skrevet i 1835. 
Folkekalender for Danmark 1856 (København u.å.), s. 37-38.

Flor til L. C. Hagen 21.01.1856, Højskolens Ungdomstid, I, s. 196.

Flor til Høgsbro 18.10.1860, Højskolens Ungdomstid, I, s. 271.

Flor til Sveistrup 08.02.1865, Hфjskolens Ungdomstid, II, s. 123.

Brev til P. C. Koch af 26.06.1841, Højskolens Ungdomstid, I, s. 5, og Da Sфnderjylland vaagnede, IV (1916), s. 198.

Se f.eks. Da Sønderjylland vaagnede, I, s. 177, 178; IV, s. 103, 181, 189, 193, 221.

Vakkelse, kirkefornyelse og nationalitetskamp i Sønderjylland 1815-1850 (Åbenrå 1977), s. 287.

Hagen havde i øvrigt været den drivende kraft i et vestslesvigsk initiativ, der allerede i november 1841 resulterede i en »Opfordring til den nordslesvigske Bondestand « om dannelse af et aktieselskab til oprettelse af en højskole (Dannevirke,

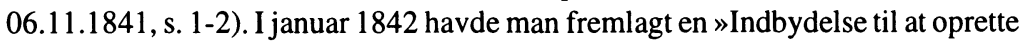
en dansk Høiskole i Sønderjylland «, hvori der var indeholdt en fuldstændig plan for en sådan skoles financiering, dens bestyrelse og dens fagkreds (indlagt $\mathrm{i}$ Dannevirke, 22.01.1842).

I kort begreb omfatter kredsen samfundskundskab, naturvidenskab, historie, specielt fædrelandets historie, geografi, dansk litteratur samt som hovedfag: modersmålet. Der kan også blive tale om sang, gymnastik og havedyrkning samt - som et valgfrit fag, der indføres med store forbehold: tysk.

F.eks. i »Nordens Mythologi«, VU IV, s. 33; »Skolen for Livet ...«, sst., s. 212213, 226; »Bøn og Begreb om en Dansk Høiskole i Soer«, sst., s. 385, 386, 392; »Lykønskning til Danmark med Det danske Dummerhoved og Den danske Høiskole«, sst., hvor det nære forhold mellem stænderforfatningen og højskolen udvikles s. 460-469.

»Til Nordmænd om en Norsk Høiskole«, VU IV, s. 192; »Skolen for Livet ...«, sts., s. 226 (»Examen og Levebrød «); »Bøn og Begreb ...«, sts., s. 387; »Brev til Christian VIII om Indretningen af Sorø Akademi til en folkelig Højskole«, sts., s. 420 (afvisning af både eksamen og forberedelse til levebrød).

Om skolerådet, se »Bøn og Begreb ...«, $V U$ IV, s. 390. Om stænderforfatningen, se f.eks. »Det danske Fiir-Kløver«, sts., s. 158; »Det danske Dummerhoved ...«, sts., s. 462-464, samt digtet »Kongen og Folket«, $V U$ VIII, s. 151-152. 

s. 16-17. Nissen og Skau til Flor, 24.09.1843, Da Sønderjylland vaagnede, VI, s. 72, Skau til Flor 28.09.1843, sts., s. 74. Jfr. også Rosendal: Nogle Bidrag ..., s. 26.

Flors rejse: Højskolens Ungdomstid, I, s. 18; Da Sønderjylland vaagnede, VI, s. 71. Deputationens rejse: sts., s. 77-78, jfr. sts., V, s. 69-75. I Dannevirke, 11.11.1843 aftrykkes - med enkelte udeladelser - Fadrelandets beretning om festen på Skydebanen 05.11. til ære for deputationen. - Muligvis kan det også have spillet en rolle, at L. C. Hagen, der havde måttet se sin egen skoleplan forlise, stadig ivrede for »en høiere Folkeskole « og afviste tanken om en dansk, lærd skole (Hagen til Ploug 23.08.1843, Da Sønderjylland vaagnede, VIII, s. 9-11.

Gunhild Nissen: Udfordringer ..., s. 51, jfr. s. 365, note 97.

Flor til Adler, 02.12.1843, samt Skau til Flor, 03.12.1843: Da Sønderjylland vaagnede, VIII, s. 11-13. Flor til P. C. Koch, 07.12.1843, Højskolens Ungdomstid, I, s. 19.

Forhandlingerne om og med Wegener: Højskolens Ungdomstid, I, s. 21-26, 32; Da Sønderjylland vaagnede, VIII, s. 13-16. Købet af gården: Skau til Flor, 17.12.1843, Højskolens Ungdomstid, I, s. 20; Syvstjernens tilsagn: sts., I, s. 27-28, Da Sønderjylland vaagnede, VIII, s. 16-19.

»Folke-Høiskolen« bestemmes som »en Anstalt, hvor Bonde og Borger kan erholde saadanne Kundskaber og Færdigheder, som kunne være ham til Nytte og Behag, ikke saameget med Hensyn til hans særegne Næringsvei og Bedrift, som med Hensyn til hans Liv og Stilling som Landets Søn og Statens Borger«.

I den af Flor udgivne Beretning om Folke-Høiskolen $i$ R $\varnothing d$ ding (København 1846) meddeles det da også (s. 5), at den omarbejdede plan »navnlig behagede den Kbhavnske Comitee bedre.« - En anden sag er så, at Flor sst. s. 8-9 forklarer, at virkeligheden ifølge sagens natur i adskilligt ikke svarer til udkastet - der kun gav sig ud for at være et forsøg; og af s. 9-10 fremgår, at der det første år kun har været én klasse. I vinteren 1845-46 har der været to, men eleverne er her inddelt efter dygtighed, og fagkredsen er stort set den samme. Af den omarbejdede plans skelnen mellem en mere realskolepræget og en mere højskolepræget afdeling er der intet spor. Heller ikke de planer om to klasser, som Flor arbejdede med i 1854, synes at have med den omarbejdede plans deling at gøre (Højskolens Ungdomstid, I, s. 150-151).

Højskolens Ungdomstid, I, s. 23.

Højskolens Ungdomstid, I, s. 45.

Flor: Beretning ..., s. 13. 
Højskolens Ungdomstid, I, s. 77.

Vilhelm Andersen i Carl S. Petersen \& Vilhelm Andersen: Illustreret dansk Litteraturhistorie, III: Det nittende Aarhundredes første Halvdel (København 1924), s. 205; Roar Skovmand i »Grundtvig og den første folkehøjskoles mænd «, Grundtvig Studier 1960, s. 31.

Søren Jensen: »Frederik Helveg og Rødding Højskole«, Vartovbogen (København 1995), s. 86-114.

»Den viborgske Comitebetænkning angaaende Forslaget om Anlæggelse af høiere Skoler paa Landet«, Dannevirke, 30.01.1847, s. 1; sst, 03.02.1847, s. 2; sst., 06.02.1847, s. 1. - Om baggrunden for komitebetænkningen se Roar Skovmand: Folkehøjskolen i Danmark 1841-1892 (København 1944), s. 27-29.

H. Rosendal: Nogle Bidrag ..., s. 63-64; Arne Fog Pedersen: Danmarks første Højskole og dens Mand (København 1944), s. 95.

Sofus Høgsbro: Mit forhold til Grundtvig, Tscherning og Monrad (København 1902), især s. 7, 9, 12-15, 19-20.

Høgsbro: Beretning om Folkeh $\emptyset$ jskolen i Rødding, i Scerdeleshed fra Novbr. 1850 til Febr. 1853 (Haderslev 1853), s. 1.

Roar Skovmand: Folkehøjskolen i Danmark, s. 47. - I artiklen i Grundtvig Studier 1960 (s. 37) erklærer Skovmand, at Vilhelm Andersens karakteristik af Rødding i Flors tid - at den var højgrundtvigsk - også kunne gælde i Høgsbros.

Høgsbro: Beretning ..., (1853) s. 25.

En fuldstændig oversigt over stridighederne kan ikke gives her. Som en nødtørftig orientering henvises der til Højskolens Ungdomstid, I, s. 107, 111, 115-117, 119124, 128-131, 134-136, 139-147, 152-153, 161-163, 165, 171-178 og 181-208, 241. Rosendal: Nogle Bidrag ..., s. 69-71, 76-88; Skovmand: Folkehøjskolen $i$ Danmark, s. 46-48; Skovmand i Grundtvig Studier 1960, s. 36-38; Ægidius: Christian Flor, s. 284-288. - Om uenigheden mellem Poulsen og Flor se Skovmand: Folkehøjskolen i Danmark, s. 24-27, 47.

Høgsbro; Mit forhold til Grundtvig ..., s. 18; Beretning om Rødding Folkehøiskole i Aaret 12te Juni 1859 til 12te Juni 1860 (København 1860), s. 23.

P. G. Lindhardt i Hal Koch og Bjørn Kornerup: Den danske kirkes historie, VII (København 1958), s. 85. Jfr. Hans Jensen: »Endnu i Halvtredserne har det været den almindelige Opfattelse af Grundtvigianerne, at det var Folk, der lagde Vægt paa at lade en ganske særlig Fromhed fremtræde udvortes i deres daglige Livsførelse, - det, der senere blev Opfattelsen af 'Missionsfolk'.« Kirkehistoriske 
Samlinger, 6. række, bind IV (København 1942-44), s. 295.

En interessant kommentar til situationen foreligger i et brev fra den tidligere elev og senere friskolelærer Lars Frederiksen til Høgsbro fra 6. oktober 1856. Han skriver: »De Forandringer som Høiskolen har undergaaet kan jeg ikke sige andet end godt om; hvis ellers Grunden til disse er den, som jeg forestiller mig. Jeg har nemlig meent at den Strid som førtes kom af, at De og Deres Parti (hvortil jeg har havt den Ære at regne mig), ville have en folkelig Udvikling som Høiskolens Bestemmelse. Medens Thomsen og hans Parti satte en videnskabelig Dannelse som det Maal hvorefter Høiskolen skulde stræbe. Men skete dette da forsvandt jo Folkehøiskolen og der kom et Landvæsensinstitut istedet; hvorved Anstalten gik ud fra sin oprindelige Bestemmelse; en Høiskole for Folket.« (Landsarkivet Aabenraa, Foreningsarkiver, Rødding Højskole, 253-54/2: Breve A-L.)

Flor i Høgsbro: Beretning ..., (1860), s. 12-21, citatet s. 15; jfr. Høgsbros selvforsvar s. 21-31; Helveg i Høgsbro: Beretning om Rødding Folkehøiskole $i$ Aaret 12te Juni 1861 til 12te Juni 1862 (København 1862), s. 10-12.

Om uenigheden mellem Høgsbro og Knudsen se Højskolens Ungdomstid, I, s. 207, 209-210; 230-239, 245, 250, 273, 276-277; jfr. udvekslingen af principielle synspunkter mellem Knudsen og Høgsbro i februar 1860, Sofus Høgsbro: Breveksling og Dagbøger, udg. af Hans Lund (København u.å.), I, s. 46-48. Endv. Rosendal: Nogle Bidrag ..., s. 77-78 (s. 78: »Med J. L. Knudsen holdt den kirkelige Grundtvigianisme egentlig sit Indtog blandt Lærerne paa Rødding Højskole.«); Skovmand i Grundtvig Studier, 1960, s. 38-39.

Høgsbro: Beretning ..., (1853), s. 25-26; Højskolens Ungdomstid, I, s. 210 (Boisen til Høgsbro 24.09.1856), 277 (Høgsbro til Flor 06.04.1861).

Brev til Hans Sveistrup af 08.02.1865, Højskolens Ungdomstid, II, s. 123.

Højskolens Ungdomstid, I, s. 45-47.

Rørdam til Grundtvig 09.08.1845, Peter Rørdam. Blade af hans Levnedsbog og Brevvexling, udgivet af H.F.Rørdam, II (København 1892), s. 32. Rørdam til Grundtvig 04.06.1847 og Grundtvig til Rørdam 12.06.1847, sts., s. 64-65. - Endnu i 1852 besøgte Rørdam Rødding og var igen meget begejstret for, hvad han oplevede. Til sin hustru skriver han »Det er underligt, at Grundtvig ei har været paa den Skole endnu ...« sts., s. 222-223. 5. 
Nordens Historiske Minder. Tale ved Den Nordiske Hфitid 1847 af Nik. Fred. Sev. Grundtvig (København u.å.), s. 26.

Rosendal: Nogle Bidrag ..., s. 57.

»Tale ved Rødding Folkehøiskoles Gienaabning d. 19. Novbr. 1850 af dens Forstander Sofus Høgsbro«, Danskeren, et Ugeblad, samlet og udgivet af Nik. Fred. Sev. Grundtvig, III (København 1850), s. 769-784.

Højskolens Ungdomstid, I, s. 191.

Utrykt brev i LA Aabenraa, Foreningsarkiver, Rødding Højskole 253-54/2: Breve A-L.

Udvalgte Skrifter, X (1909), s. 522. - Med Slien sigtes der vel til Peter Hiort Lorenzen i stænderforsamlingen i Slesvig.

Om dette se Kai Hørby: »Grundtvigs højskoletanke og Sorø Akademis reform 1842-1849«, Årbog for Dansk Skolehistorie 1967, s. 59-84. - Den kgl. resolution af 1847 om akademiets fremtidige organisation er aftrykt i Grundtvigs skoleverden i tekster og udkast, udg. af Knud Eyvin Bugge (København 1968), II, s. 322-324.

Grundtvigs skoleverden ..., II (København 1968), s. 273.

64 Ingemann til Grundtvig 01.01.1849, Grundtvig og Ingemann. Brevvexling 18211859, udg. af Svend Grundtvig (København 1882), s. 301.

Dansk Folketidende, nr. 46, 12.11.1869, s. 2. 